\section{PENGARUH KEPUASAN WAJIB PAJAK, PENEGAKAN SANKSI PAJAK DAN KEADILAN DISTRIBUTIF TERHADAP KEPATUHAN WAJIB PAJAK DI KOTA PONTIANAK}

\author{
JOKO SUSENO, SANI
}

Akademi Perpajakan Panca Bhakti Pontianak

seno_rdk@yahoo.com,sanni.semm@yahoo.com
Tax payers satisfaction, Compliance tax payer

\begin{abstract}
The aims of study are analyzing the impact of satisfaction from the taxpayers, tax sanction enforcement and distributive justice on taxpayer compliance, especially taxpayer of construction service companies. Data has been collected by closed questionnaire with Likert scale between 1 and 5. From the statement, it can know the level of taxpayer compliance as the respondent to the problem determined by the way of providing value to answers result from the respondents. Multiple regression analysis has been used to analyze data. Based on the research, it shows that taxpayer satisfaction variable can be proved by having a positive and significant influence on taxpayer compliance especially taxpayer of construction service company by coefficient result $\beta=0,383$ with $p$-value equal to 0,0095 smaller than $\alpha$ $=0,05$, variables Enforcement of tax sanctions has been proven by having a positive and significant impact on taxpayer compliance, especially Construction Services Company coefficient $\beta=0.943$ with $p$-value of 0.014 smaller than $\alpha=0.05$. And distributive justice variable has positive and significant influence on taxpayer compliance especially Construction Service Company with result of coefficient $\beta=$ 0,749 with $p$-value equal to $=0,0185$ smaller than $\alpha=0,05$
\end{abstract}

Keyword : tax payers satisfaction, tax sanction enforcement, distributive justice compliance tax payer

\title{
PENDAHULUAN
}

\section{Latar Belakang}

Pajak merupakan sumber penerimaan utama bagi pemerintah daerah dan pemerintah pusat yang digunakan untuk membiayai pengeluaran rutin pemerintah dan pembangunan nasional. Hal ini tertuang dalam Anggaran Penerimaan dan Belanja Negara (APBN) dimana penerimaan negara dari sektor pajak merupakan yang paling besar yaitu Sebesar 85,5\% Penerimaan Negara Republik Indonesia bersumber dari sektor perpajakan (Nota Keuangan dan APBN Tahun Anggaran 2016), Oleh karena itu Pemerintah terus 
Tax payers satisfaction, Compliance tax payer

\section{2}

berusaha menaikkan target penerimaan Pajak dari tahun ke tahun, hal ini dimaksudkan agar program-program Pemerintah dalam menjalankan roda Pemerintahan untuk meningkatkan kesejahteraan masyarakat dapat ditingkatkan juga. Sebagaimana kita ketahui bersama kesadaran dan kepedulian masyarakat Indonesia terhadap Pajak masih sangat kurang meskipun tahun-tahun terakhir ini terdapat peningkatan yang sangat baik, tetapi tetap saja sebagian besar masyarakat masih awam tentang pajak, baik cara melaksanakan kewajiban perpajakan dan yang tidak kalah pentingnya adalah kurangnya pengetahuan tentang manfaat dan kegunaan pajak bagi kehidupan berbangsa dan bernegara. Pajak merupakan iuran wajib yang diberlakukan pada setiap wajib pajak atas objek pajak yang dimilikinya dan hasilnya diserahkan kepada pemerintah. Terhambatnya penerimaan pajak akan menghambat kelancaran pelaksanaan pembangunan, oleh karena itu agar pembangunan tidak terhambat maka upaya peningkatan kepatuhan wajib pajak dalam membayar pajak penghasilan dan pajak lainya harus dipacu dan ditingkatkan oleh semua aparat pemungut pajak. Oleh karena itu agar peraturan perpajakan dipatuhi oleh seluruh wajib pajak, maka harus ada sanksi perpajakan bagi pelanggarnya.

Sanksi perpajakan merupakan jaminan bahwa ketentuan peraturan perundangundangan perpajakan (norma perpajakan) akan dituruti/ ditaati/ dipatuhi, dengan kata lain sanksi perpajakan merupakan alat pencegah agar wajib pajak tidak melanggar norma perpajakan (Mardiasmo, 2011). Sanksi perpajakan merupakan pemberian sanksi bagi wajib pajak yang tidak memenuhi kewajibannya sesuai dengan ketentuan peraturan perundang-undangan perpajakan yang berlaku. Terdapat Undang-Undang Nomor 16 Tahun 2009 yang mengatur tentang ketentuan umum dan tata cara perpajakan. Agar peraturan perpajakan dipatuhi, maka harus ada sanksi perpajakan bagi para pelanggarnya. Tinggi rendahnya wajib pajak dalam mematuhi kewajiban perpajakannya dipengaruhi oleh beberapa faktor, salah satunya adalah kesadaran wajib pajak.

Kesadaran wajib pajak adalah suatu kondisi di mana wajib pajak mengetahui, memahami, dan melaksanakan ketentuan perpajakan dengan benar dan sukarela. Pemahaman tentang pajak serta kesungguhan wajib pajak untuk melaporkan dan membayar kewajiban perpajakannya dapat mencerminkan tingkat kesadaran wajib pajak. Apabila kesadaran masyarakat atas perpajakan masih rendah maka akan menyebabkan banyaknya potensi pajak yang tidak dapat dimanfaatkan. Sosialisasi juga sangat penting dalam meningkatkan kesadaran masyarakat untuk membayar pajak. Tinggi rendahnya 
kepatuhan pajak juga dipengaruhi oleh kualitas pelayanan. Semakin baik kualitas pelayanan akan menyebabkan semakin tingginya tingkat kepatuhan wajib pajak.

Upaya peningkatan kualitas pelayanan meliputi segala jenis pelayanan yang berhubungan dengan proses pemenuhan kewajiban maupun hak wajib pajak dibidang perpajakan misalnya pelayanan yang cepat di Kantor Pelayanan Pajak, kemudian

Tax payers satisfaction, Compliance tax payer komplain yang cepat petugas pajak terkait permasalahan-permasalahan perpajakan di Kantor Pelayanan Pajak dan respon yang cepat dari petugas pajak terkait permintaan informasi pelaporan perpajakan serta kemudahan tata cara pembayaran, kecakapan petugas pajak dalam melayani hingga penampilan petugas pajak. Wajib Pajak akan cenderung meningkatkan kepatuhan pajak apabila wajib pajak merasa puas akan pelayanan yang diberikan oleh petugas pajak dalam melayani kebutuhannya selama mengurus pajak. Kepatuhan wajib pajak merupakan suatu ketaatan untuk melakukan ketentuan-ketentuan atau aturan-aturan perpajakan yang diwajibkan atau diharuskan untuk dilaksanakan oleh setiap wajib pajak.

Perilaku Wajib Pajak yang tidak sepenuhnya memenuhi kewajiban perpajakan dapat dibedakan menjadi tax avoidance dan tax evasion (Lubis, 2010). Tax avoidance merupakan usaha meringankan beban pajak oleh wajib pajak dengan tidak melanggar peraturan perundangan yang berlaku. Tax evasion merupakan usaha meringankan beban pajak dengan cara penyelundupan pajak dan melanggar peraturan perundangan yang berlaku. Melihat pentingnya kepatuhan wajib pajak, maka pemerintah daerah harus menyentuh persepsi keadilan wajib pajak. Salah satu variabel nonekonomi kunci dari perilaku kepatuhan pajak adalah dimensi keadilan pajak (Dharmawan, 2012). Wajib pajak cenderung untuk menghindari membayar pajak jika mereka menganggap sistem pajak tidak adil. Persepsi keadilan yang diperoleh oleh wajib pajak dapat dikelompokkan menjadi keadilan distributif, prosedural dan interaksional.

Kepatuhan wajib pajak dapat diwujudkan dengan penegakan sanksi. Koentarto (2011) dan Sanjaya (2014) menemukan penegakan sanksi mempunyai pengaruh pada kepatuhan masyarakat dalam melakukan pembayaran Pajak Bumi dan Bangunan. Hasil yang berbeda ditemukan oleh Maryati (2014), bahwa secara parsial sanksi pajak tidak berpengaruh signifikan pada kepatuhan wajib pajak orang pribadi di KPP Pratama Bintan. Penelitian empiris tentang kepatuhan wajib pajak dilakukan oleh Albari (2008) tentang 
Tax payers satisfaction, Compliance tax payer

\section{4}

pengaruh keadilan terhadap kepuasan dan kepatuhan wajib pajak. Penelitian ini berhasil membuktikan adanya pengaruh yang signifikan keadilan pada kepatuhan wajib pajak melalui variabel antara kepuasan.

Penelitian ini mengenai kepatuhan wajib pajak, dengan menguji pengaruh variabel kepuasan wajib pajak, penegakan sanksi pajak dan keadilan distributif pada kepatuhan wajib pajak. Penulis meneliti kepatuhan wajib pajak dikarenakan sering terjadinya pelanggaran dan tunggakan terhadap pembayaran pajak baik itu secara meringankan beban pajak dengan cara penggelapan pajak(Tax Evasion) maupun pun secara meringankan beban pajak atau dengan cara pengelakan pajak (Tax Avoidance). Pada penelitian ini difokuskan pada pembahasan keadilan distributif, karena pada beberapa penelitian sebelumnya tentang pengaruh keadilan pada kepatuhan wajib pajak dapat menunjukan hasil yang berbeda-beda tentang dimensi keadilan distributif pada kepatuhan wajib pajak.

Dalam mewujudkan kepatuhan wajib pajak, disamping memperhatikan faktor eksternal seperti penegakan sanksi perlu juga dipertimbangkan faktor internal wajib pajak. Sedangkan ditinjau dari teori keadilan, bahwa wajib pajak membandingkan pajak yang dibayar apakah sudah sesuai dengan manfaat yang didapatkan dari pemerintah dan dibandingkan dengan wajib pajak yang lain apakah memperoleh manfaat yang lebih besar dengan membayar pajak lebih kecil. Dengan diterapkanya sistem pemungutan pajak yang sudah adil diharapkan dapat menghilangkan rasa ketidakadilan atara wajib pajak. Penelitian ini dilaksanakan di Kota Pontianak Provinsi Kalimantan Barat. Penelitian ini menggunakan Analisis Regresi Linier Berganda untuk mengetahui arah hubungan antara variabel independen dengan variabel dependen.

\section{Permasalahan}

1. Bagaimana pengaruh kepuasan wajib pajak terhadap kepatuhan wajib pajak?

2. Bagaimana pengaruh penegakan sanksi pajak terhadap kepatuhan wajib pajak?

3. Bagaimana pengaruh keadilan distributif terhadap kepatuhan wajib pajak ? 


\section{TINJAUAN PUSTAKA}

\section{Teori Keadilan (Equity Theory)}

Tax payers satisfaction, Compliance tax payer dibandingkan dengan keadilan distributif. Apabila prosedur yang digunakan dalam pengambilan keputusan sudah dapat memberikan keadilan, seseorang tidak akan terlalu mempertimbangkan hasil yang diperoleh. Menurut Ulupui (2005) keadilan distributif berkaitan dengan outcome karena penekanannya pada distribusi yang diterima tanpa mempertimbangkan bagaimana penentuan distribusi tersebut dilakukan. Jika individu menilai perlakuan yang mereka terima adil dari dari sisi distribusi dan prosedur maka akan berpengaruh pada dua jenis outcomes, yaitu kepuasan karyawan dan komitmen karyawan. Namun dalam penelitian ini keadilan distributif yang dipandang lebih tepat bagi peneliti dalam menjelaskan variabel kepatuhan wajib pajak karena adanya interaksi dengan kepuasan wajib pajak.

Robbins (2008) menyebutkan teori keadilan adalah suatu teori bahwa individu membandingkan masukan-masukan dan hasil pekerjaan mereka dengan masukanmasukan dan hasil pekerjaan orang lain dan kemudian merespons untuk menghilangkan ketidakadilan. Pada awalnya teori keadilan berfokus pada keadilan distributif (distributive justice), yaitu keadilan jumlah dan pemberian penghargaan diantara individu-individu. Keadilan distributif merupakan tingkat kelayakan hasil akhir kegiatan yang dirasakan pelanggan dari keluhan mereka, meskipun bukan berarti harus menguntungkan atau tidak menguntungkan pelanggan.

\section{Teori Atribusi (Atribution theory)}

Menurut Lubis (2010) teori atribusi mempelajari proses bagaimana seseorang menginterpretasikan suatu peristiwa, alasan, atau sebab perilakunya. Berdasarkan hal tersebut, seseorang akan termotivasi untuk memahami lingkungannya dan sebab-sebab kejadian tertentu. Teori ini dalam riset keperilakuan diterapkan dengan menggunakan variabel tempat pengendalian (locus of control). Variabel tersebut terdiri atas dua komponen, yaitu tempat pengendalian internal (internal locus of control) dan tempat pengendalian eksternal (external locus of control). Tempat pengendalian internal adalah perasaan yang dialami oleh seseorang bahwa dia mampu mempengaruhi kinerja serta perilakunya secara personal melalui kemampuan, keahlian, dan usahanya, sementara 
Tax payers satisfaction, Compliance tax payer

tempat pengendalian eksternal adalah perasaan yang dialami seseorang bahwa perilakunya dipengaruhi oleh factor-faktor diluar kendalinya.

Teori atribusi mempelajari proses bagaimana seseorang menginterpretasikan suatu peristiwa dan mempelajari bagaimana seseorang menginterpretasikan alasan atau sebab perilakunya (Suartana, 2010). Kepatuhan wajib pajak terkait dengan sikap wajib pajak dalam membuat penilaian terhadap pajak itu sendiri. Teori atribusi menyatakan bahwa bila individu-individu mengamati perilaku seseorang, mereka mencoba untuk menentukan apakah itu ditimbulkan secara internal atau eksternal (Robbins, 2008). Perilaku yang disebabkan secara internal adalah perilaku yang diyakini berada di bawah kendali pribadi individu itu sendiri. Sedangkan perilaku yang disebabkan secara eksternal adalah perilaku yang dipengaruhi dari luar, artinya individu akan terpaksa berperilaku karena situasi. Penentuan internal atau eksternal suatu perilaku menurut Robbins (2008) bergantung pada tiga faktor yaitu Kekhususan, Konsensus dan Konsistensi.

\section{Kepatuhan Wajib Pajak}

\section{Pengertian Kepatuhan}

Pengukuran kepatuhan, sangat penting untuk mengetahui apa yang akan diukur seperti evasion, avoidance, kepatuhan atau ketidakpatuhan. Dalam mendefinisikan kepatuhan perlu dipahami kriteria yang mendasari pendefinisian kepatuhan apakah definisi tersebut didasarkan pada otoritas pajak, interprestasi wajib pajak pada hukum dan yang terakhir opsi yang lebih netral. Menurut Organisation for Economic Co-operation and Development (OECD), dalam mempertimbangkan definisi kepatuhan, akan lebih mudah jika kepatuhan dibagi dalam dua kategori utama antara lain 1. Kepatuhan administratif yaitu kepatuhan pada aturan administratif seperti pembayaran tepat waktu. Definisi yang terkandung dalam kepatuhan administratif mencakup persyaratan pelaporan, kepatuhan prosedural atau kepatuhan akan peraturan. 2. Kepatuhan teknis yaitu kepatuhan yang dilakukan dengan menghitung pajak sesuai dengan persyaratan teknis hukum pajak dan wajib pajak membayar bagian pajak yang harus mereka bayar sesuai dengan ketentuan Undang-Undang pajak. Sehingga kepatuhan wajib pajak merupakan bentuk loyalitas wajib pajak pada aturan perpajakan yang yang dikeluarkan oleh pemerintah. 
Simon James, et al yang dikutip oleh Gunadi (2005) menyebutkan kepatuhan pajak adalah perilaku wajib pajak untuk kewajibannya tanpa adanya intervensi berupa audit, investigasi maupun penegakan sanksi. Secara sederhana kepatuhan yang dimaksud adalah kepatuhan secara sukarela. Kepatuhan sukarela menjadi dasar penerapan self assessment system pengenaan pajak. Self assessment system merupakan sistem pemungutan dengan

kesadaran dari aktivitas masyarakat itu sendiri untuk menghitung, memperhitungkan, membayar dan melaporkan sendiri jumlah pajak terhutang (Lubis, 2010). Wajib pajak yang patuh menurut Peraturan Menteri Keuangan (PMK) Nomor 192/PMK.03/2007 tentang Tata Cara Penetapan Wajib Pajak Dengan Kriteria Tertentu Dalam Rangka Pengembalian Pendahuluan Kelebihan Pembayaran Pajak memiliki kriteria yaitu Kepatuhan penyerahan SPT, Kepatuhan pembayaran dan Kepatuhan pelaporan.

\section{Pengertian Wajib Pajak}

Pengertian Wajib Pajak yang termuat dalam Pasal 1 angka 1 Undang-Undang Nomor 16 Tahun 2009 tentang Ketentuan Umum dan Tata Cara Perpajakan yaitu Wajib Pajak adalah orang pribadi atau badan, meliputi pembayar pajak, pemotong pajak, dan pemungut pajak, yang mempunyai hak dan kewajiban perpajakan sesuai dengan ketentuan peraturan perundang-undangan. Definisi tersebut menuntut wajib pajak untuk melakukan kewajiban perpajakanya termasuk pemungut pajak atau pemotong pajak tertentu. Oleh karena itu pemerintah terus mengupayakan agar wajib pajak memahami sepenuhnya kewajiban terhadap Negara dan mau melaksanaanya dengan itikad baik kewajiban perpajakanya. Lebih lanjut dijelaskan bahwa yang menjadi wajib pajak Penghasilan adalah orang pribadi atau badan yang memperoleh penghasilan baik dalam negeri maupun dari luar negeri.

Wajib pajak dibedakan menjadi dua yaitu wajib pajak orang pribadi dan wajib pajak badan. Berdasarkan pasal 2 ayat 3 (a) dalam undang-undang No. 36 Tahun 2008 tentang pajak penghasilan yang dimaksud denga wajib pajak orang pribadi pada prinsipnya adalah orang pribadi yang menjadi subjek pajak dalam negeri orang pribadi yang bertempat tinggal di Indonesia, orang pribadi yang berada di Indonesia lebih dari 183 (seratus delapan puluh tiga) hari dalam jangka waktu 12 (dua belas) bulan, atau orang pribadi yang dalam suatu tahun pajak berada di Indonesia dan mempunyai niat untuk bertempat tinggal di Indonesia. 
Tax payers satisfaction, Compliance tax payer

\section{Penegakan Sanksi}

Sanksi adalah suatu tindakan berupa hukuman yang diberikan kepada seseorang yang melanggar peraturan. Peraturan atau undang-undang merupakan rambu-rambu bagi seseorang untuk melakukan sesuatu mengenai apa yang harus dilakukan dan apa yang seharusnya tidak dilakukan. Sanksi diperlukan agar peraturan atau undang-undang tidak dilanggar, sanksi perpajakan diberlakukan untuk menciptakan kepatuhan Wajib Pajak dalam melaksanakan kewajiban perpajakannya. Dengan kata lain, sanksi perpajakan merupakan alat pencegah (preventif) agar Wajib Pajak tidak melanggar norma, itulah sebabnya, penting bagi Wajib Pajak memahami sanksi-sanksi perpajakan sehingga mengetahui konsekuensi hukum dari apa yang dilakukan ataupun tidak dilakukan.

Jatmiko (2006) menyebutkan sanksi adalah hukuman negatif kepada orang yang melanggar peraturan, dan denda adalah hukuman dengan cara membayar uang karena melanggar peraturan dan hukum yang berlaku. Sanksi denda yang dimaksud adalah hukuman yang bersifat negatif berupa membayar dengan uang sebagai akibat dari melanggar peraturan. Di dalam undang-undang No 16 tahun 2009 terdapat dua sanksi yaitu sanksi Administrasi dan Sanksi Pidana.

\section{Kepuasan Wajib Pajak}

Wajib pajak merupakan faktor utama yang menentukan sukses atau tidaknya kegiatan pemungutan dan pengumpulan pajak. Oleh karena itu, eksistensinya harus mendapatkan tempat yang paling terhormat seperti mendapatkan pelayanan yang terbaik, kebutuhannya akan kemudahan, kenyamanan dan kepastian hukum harus dijamin. Pada kenyataannya, banyak wajib pajak merasa menemui hambatan dalam proses pelayanan yang diberikan aparatur perpajakan seperti petugas yang lamban, menunggu terlalu lama, layanan yang kurang nyaman, fasilitas yang tidak memadai, dan lain sebagainya yang menimbulkan adanya keluhan, complain, dan keengganan wajib pajak menyelesaikan kewajiban perpajakannya. Pada akhirnya akan berakibat pada tumbuhnya sikap tidak patuh dalam melaksanakan kewajiban perpajakan.

Masih banyaknya wajib pajak yang belum membayar pajak, diduga merupakan indikasi semakin menurunnya kualitas layanan atau tidak terpenuhinya kepuasan wajib pajak, karena tidak sesuai dengan layanan yang diharapkan yang menyebabkan banyak 
wajib pajak tidak melaksanakan sebagian bahkan seluruh kewajibannya. Ini merupakan masalah yang harus dicarikan solusinya sebelum semakin banyak wajib pajak yang tidak melaksanakan kewajibannya dikarenakan semakin tidak puasnya wajib pajak terhadap layanan yang diberikan petugas pajak, maka akan berdampak pada penurunan penerimaan pajak. Kualitas pelayanan sebagai suatu kondisi dinamis yang berhubungan dengan produk, jasa, manusia, produsen dan lingkungannya yang memenuhi atau melebihi harapan. Kualitas layanan diartikan sebagai sesuatu yang berhubungan dengan terpenuhinya harapan/kebutuhan pengguna layanan, di mana pelayanan dikatakan berkualitas apabila dapat menyediakan produk dan jasa pelayanan sesuai dengan kebutuhan dan harapan pengguna layanan.

\section{Hipotesis Penelitian}

H1 : Kepuasan Wajib Pajak berpengaruh positif terhadap kepatuhan wajib pajak

H2 : Penegakan sanksi pajak berpengaruh positif terhadap kepatuhan wajib pajak.

H3 : Keadilan distributif berpengaruh positif terhadap kepatuhan wajib pajak.

\section{Kerangka Pemikiran}

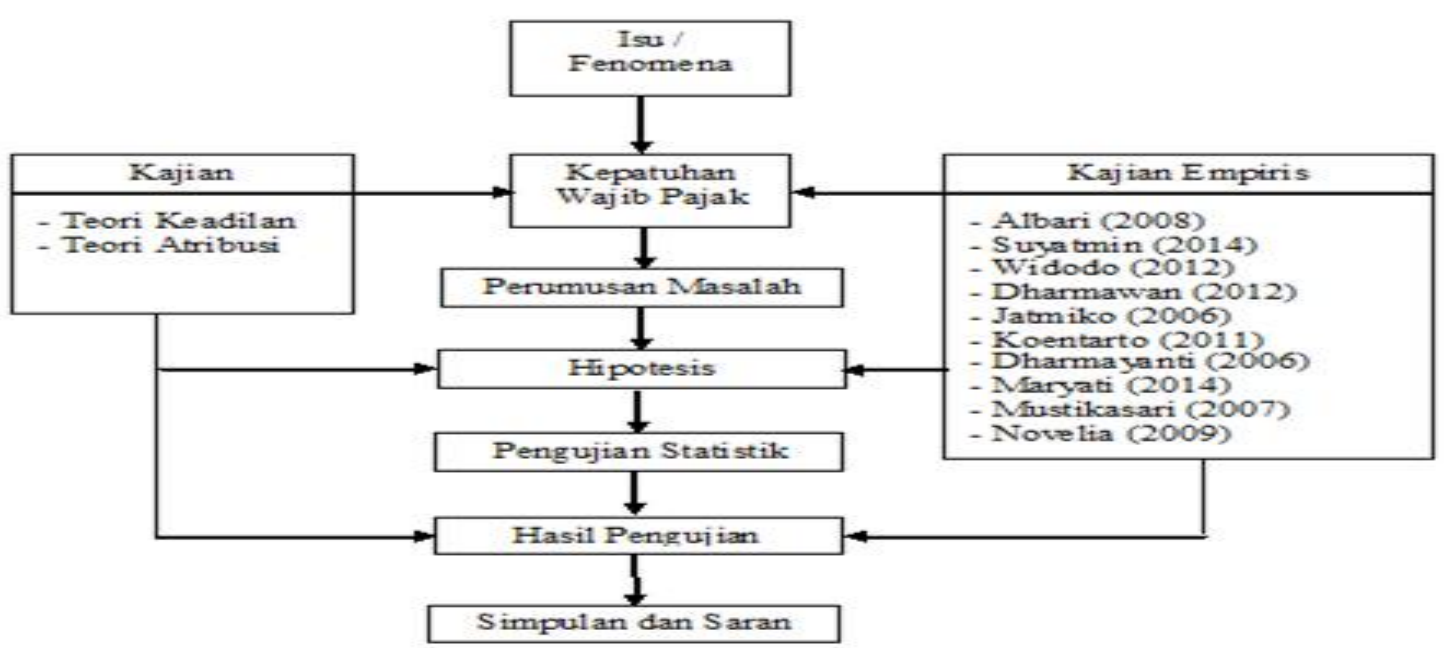

\section{Model penelitian}

Penelitian ini merupakan penelitian untuk menguji pengaruh kepuasan wajib pajak, penegakan sanksi pajak dan keadilan distributif pada kepatuhan wajib pajak. Berdasarkan hal tersebut konsep penelitian ini dapat disajikan dalam gambar berikut ini. 
Tax payers satisfaction, Compliance tax payer

\section{0}

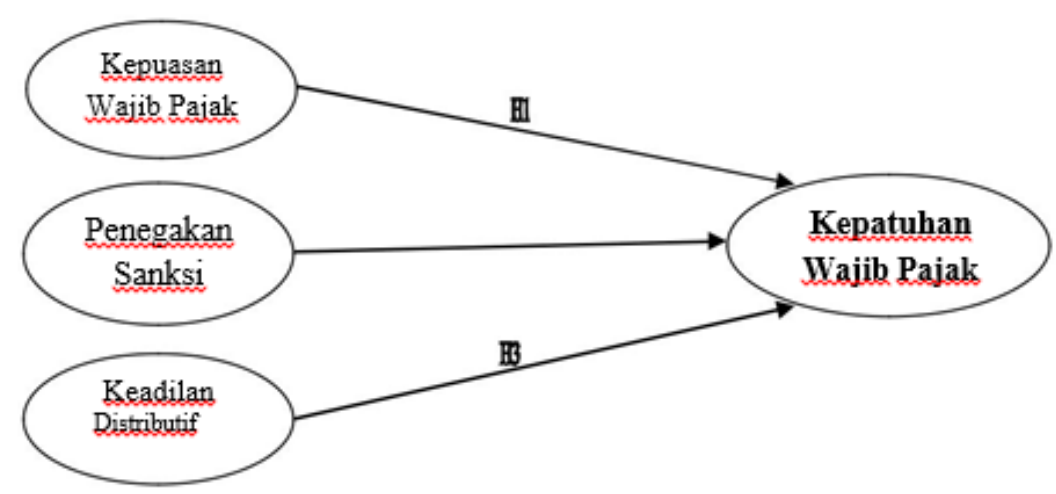

\section{Rancangan Penelitian}

Rancangan penelitian yang baik perlu dirancang aktivitas dan sumber dayanya dengan baik. Rancangan penelitian adalah rencana dari struktur penelitian yang mengarahkan proses dan hasil riset sedapat mungkin menjadi valid, obyektif, efisien dan efektif (Jogiyanto, 2004). Rancangan penelitian memberikan alur penelitian dari mempersiapkan data penelitian, menguji hipotesis yang pada akhirnya memberikan kesimpulan. Pengujian statistik dilakukan setelah penentuan sampel, sumber datanya, dan metode pengumpulan datanya. Hasil analisis kemudian diinterprestasikan untuk menjawab permasalahan yang ada.

\section{Lokasi dan Waktu Penelitian}

Penelitian ini dilakukan di Kota Pontianak dengan cara menyebarkan kuesioner kepada wajib Pajak badan khususnya Perusahaan Jasa Konstruksi yang tergabung dalam Gabungan Pelaksana Konstruksi Nasional Indonesia wilayah Kota Pontianak Propinsi Kalimantan Barat. Penelitian ini dilaksanakan pada tahun 2015 dan 2016.

\section{Penentuan Sumber Data}

Sumber data dalam penelitian ini merupakan data primer yaitu data yang diperoleh langsung dari responden yaitu wajib pajak badan Perusahaan Jasa Konstruksi. Responden penelitian ini adalah pemilik dari Perusahaan Jasa Konstruksi yang ada di Kota Pontianak Propinsi Kalimantan Barat.

Pengumpulan data dilakukan dengan menggunakan metode survei dengan teknik pengumpulan data menggunakan kuesioner. Kuesioner yang digunakan merupakan 
kuesioner yang digunakan oleh beberapa peneliti terdahulu dengan melakukan sedikit modifikasi. Kuisioner yang digunakan adalah kuisioner tertutup dengan skala likert antara 1 sampai denga 5. Dari pernyataan tersebut dapat diketahui tingkat kepatuhan wajib pajak sebagai responden terhadap masalah yang ditentukan yaitu dengan cara memberikan nilai (skor) terhadap hasil jawaban dari responden, yaitu :

\begin{tabular}{|l|l|l|l|l|}
\hline Sangat Setuju & Setuju & Cukup Setuju & Kurang Setuju & Tidak Setuju \\
\hline SS & S & CS & KS & TS \\
Skor 5 & Skor 4 & Skor 3 & Skor 2 & Skor $\quad 1$ \\
\hline
\end{tabular}

\section{Populasi dan Sampel}

Populasi dalam penelitian ini adalah seluruh wajib pajak badan Perusahaan Jasa Konstruksi yang ada di Kota Pontianak. Alasan peneliti mengambil populasi wajib pajak badan perusahaan jasa konstruksi karena adanya penafsiran yang berbeda diantara wajib pajak tentang pemotongan Pajak penghasilan yang berkaitan dengan jasa konstruksi yaitu ada yang berpendapat jasa konstruksi merupakan objek pajak penghasilan Pasal 23 dan sebagian berpendapat jasa konstruksi merupakan objek pajak penghasilan pasal 4 ayat (2). Selain itu dikarenakan semakin berkembangnya perusahaan jasa kontruksi di kota Pontianak, Sampai dengan usulan penelitian ini di buat jumlah Perusahaan Jasa Konstruksi yang tergabung dalam Gabungan Pelaksana Konstruksi Nasional Indonesia wilayah Pontianak pada tahun 2015 sejumlah 283 Perusahaan Jasa Konstruksi

Mengingat tidak memungkinkan untuk diambil seluruh unit populasi dengan mempertimbangkan kemampuan peneliti yang dipandang dari segi waktu, dana dan fasilitas serta dukungan lainya, maka tidak mungkin pula untuk dilakukan secara sensus,

\section{Rancangan Penelitian}

Rancangan penelitian yang baik perlu dirancang aktivitas dan sumber dayanya dengan baik. Rancangan penelitian adalah rencana dari struktur penelitian yang mengarahkan proses dan hasil riset sedapat mungkin menjadi valid, obyektif, efisien dan efektif (Jogiyanto, 2004). Rancangan penelitian memberikan alur penelitian dari mempersiapkan data penelitian, menguji hipotesis yang pada akhirnya memberikan kesimpulan. Pengujian statistik dilakukan setelah penentuan sampel, sumber datanya, dan 
Tax payers satisfaction, Compliance tax payer

ıetode pengumpulan datanya. Hasil analisis kemudian diinterprestasikan untuk ıenjawab permasalahan yang ada.

\section{Lokasi dan Waktu Penelitian}

Penelitian ini dilakukan di Kota Pontianak dengan cara menyebarkan kuesioner kepada wajib Pajak badan khususnya Perusahaan Jasa Konstruksi yang tergabung dalam Gabungan Pelaksana Konstruksi Nasional Indonesia wilayah Kota Pontianak Propinsi Kalimantan Barat. Penelitian ini dilaksanakan pada tahun 2015 dan 2016.

\section{Penentuan Sumber Data}

Sumber data dalam penelitian ini merupakan data primer yaitu data yang diperoleh langsung dari responden yaitu wajib pajak badan Perusahaan Jasa Konstruksi. Responden penelitian ini adalah pemilik dari Perusahaan Jasa Konstruksi yang ada di Kota Pontianak Propinsi Kalimantan Barat.

Pengumpulan data dilakukan dengan menggunakan metode survei dengan teknik pengumpulan data menggunakan kuesioner. Kuesioner yang digunakan merupakan kuesioner yang digunakan oleh beberapa peneliti terdahulu dengan melakukan sedikit modifikasi. Kuisioner yang digunakan adalah kuisioner tertutup dengan skala likert antara 1 sampai denga 5. Dari pernyataan tersebut dapat diketahui tingkat kepatuhan wajib pajak sebagai responden terhadap masalah yang ditentukan yaitu dengan cara memberikan nilai (skor) terhadap hasil jawaban dari responden, yaitu :

\begin{tabular}{|l|l|l|l|l|}
\hline Sangat Setuju & Setuju & Cukup Setuju & Kurang Setuju & Tidak Setuju \\
\hline SS & S & CS & KS & TS \\
Skor 5 & Skor 4 & Skor 3 & Skor 2 & Skor 1 \\
\hline
\end{tabular}

\section{Populasi dan Sampel}

Populasi dalam penelitian ini adalah seluruh wajib pajak badan Perusahaan Jasa Konstruksi yang ada di Kota Pontianak. Alasan peneliti mengambil populasi wajib pajak badan perusahaan jasa konstruksi karena adanya penafsiran yang berbeda diantara wajib pajak tentang pemotongan Pajak penghasilan yang berkaitan dengan jasa konstruksi yaitu ada yang berpendapat jasa konstruksi merupakan objek pajak penghasilan Pasal 23 dan 
sebagian berpendapat jasa konstruksi merupakan objek pajak penghasilan pasal 4 ayat (2). Selain itu dikarenakan semakin berkembangnya perusahaan jasa kontruksi di kota Pontianak, Sampai dengan usulan penelitian ini di buat jumlah Perusahaan Jasa Konstruksi yang tergabung dalam Gabungan Pelaksana Konstruksi Nasional Indonesia wilayah Pontianak pada tahun 2015 sejumlah 283 Perusahaan Jasa Konstruksi

Mengingat tidak memungkinkan untuk diambil seluruh unit populasi dengan mempertimbangkan kemampuan peneliti yang dipandang dari segi waktu, dana dan fasilitas serta dukungan lainya, maka tidak mungkin pula untuk dilakukan secara sensus, yaitu mengambil seluruh perusahaan yang menjadi sasaran penelitian. Untuk itu diperlukan teknik penentuan sampel penelitian. Pengambilan sampel dilakukan dengan metode random sampling dengan memperhatikan saran Roscoe dalam Hernawan, (2006) yang menyatakan syarat ukuran sampel yang layak dalam penelitian adalah antara 30 sampai dengan 500. Metode yang digunakan untuk menentukan jumlah sampel dalam penelitian ini menggunakan rumus Slovin, dengan hasil perhitungan jumlah sampel sebanyak 73 wajib pajak Perusahaan Jasa Konstruksi yang ada kota Pontianak.

\section{Variabel Penelitian dan Definisi Operasional Variabel Penelitian}

Variabel penelitian adalah sesuatu hal yang berbentuk apa saja yang ditetapkan peneliti untuk dipelajari dan ditarik kesimpulannya. Menurut Sugiyono (2012) variabel independen adalah variabel yang mempengaruhi atau yang menjadi sebab perubahannya atau timbulnya variabel dependen. Variabel dependen merupakan variabel yang dipengaruhi atau yang menjadi akibat, karena adanya variabel bebas. Variabel dependen dalam penelitian ini adalah kepatuhan wajib pajak dan variabel independennya yaitu kepuasan wajib pajak, penegakan sanksi pajak dan keadilan distributif.

\section{Definisi Operasional}

\section{Kepatuhan wajib pajak}

Kepatuhan wajib pajak yang dimaksud dalam penelitian ini adalah kepatuhan pada aturan administratif. Indikator kepatuhan wajib pajak yaitu kepatuhan penyerahan SPT (filing compliance), kepatuhan pembayaran (payment compliance) dan kepatuhan 
Tax payers satisfaction, Compliance tax payer

pelaporan (reporting compliance). Indikator ini menggunakan indikator penelitian dari Mustikasari (2007) dengan sedikit dimodifikasi, dalam penelitian ini menggunakan sepuluh pertanyaan dan semua item pertanyaan tersebut diukur dengan menggunakan skala Likert dengan lima item jawaban berskala. Angka 1 menunjukkan jawaban sangat tidak setuju dan angka 5 menunjukkan jawaban sangat setuju, yang artinya jawaban semakin mendekati angka 5 maka tingkat kepatuhan wajib pajak akan semakin tinggi.

\section{Kepuasan Wajib Pajak}

Kepuasan wajib pajak adalah perasaan senang atau kecewa seseorang yang muncul setelah membandingkan antara persepsi atau kesan terhadap pelayanan publik atau pemerintah. Kepuasan wajib pajak dalam penelitian ini diukur menggunakan salah satu dimensi kualitas pelayanan yaitu responsiveness (daya tanggap). Respon yang cepat terhadap keluhan wajib pajak diperlukan karena sebagai pelaku bisnis waktu menjadi hal yang sangat penting. Indikator dimensi responsiveness yaitu pelayanan cepat, respon komplain, respon permintaan informasi. penelitian ini menggunakan empat pertanyaan dengan menggunakan skala numerik 5 poin

\section{- Penegakan Sanksi Pajak}

Penegakan sanksi dalam penelitian ini adalah pelaksanaan sanksi terhadap wajib pajak yang tidak memenuhi kewajiban perpajakannya dan pelanggaran terhadap ketentuan umum perpajakan. Indikatornya adalah sanksi administrasi berupa denda dan sanksi terhadap pelanggaran atau pidana. Dalam penelitian menggunakan empat pertanyaan dengan menggunakan skala numerik 5 poin. Angka 1 menunjukkan jawaban sangat tidak setuju dan angka 5 menunjukkan jawaban sangat setuju, yang artinya jawaban semakin mendekati angka 5 maka tingkat penegakan sanksi akan semakin tinggi.

\section{Keadilan Distributif}

Keadilan distributif didefinisikan sebagai persepsi dan atau pandangan dan penilaian seseorang atas outcome atau hasil yang diterima wajib pajak dari pelaksanaan kewajibannya untuk membayar pajak. Seseorang akan semakin memperhatikan keadilan distributif dari otoritas pajak ketika seseorang tersebut percaya terhadap otoritas pajak, sebaliknya seseorang akan semakin kurang memperhatikan keadilan distributif dari otoritas pajak ketika seseorang tersebut tidak percaya terhadap otoritas pajak. Semua item 
pertanyaan tersebut diukur dengan menggunakan skala Likert dengan lima item jawaban berskala. Angka 1 menunjukkan jawaban sangat tidak setuju dan angka 5 menunjukkan jawaban sangat setuju
Tax payers satisfaction, Compliance tax payer

\section{Metode Analisis Data}

\section{Pengujian Instrumen Penelitian}

Uji validitas digunakan mengetahui kevalidan setiap pertanyaan dalam kuesioner. Uji ini merupakan uji validitas internal dengan menggunakan korelasi Product Moment dan Uji Reliabilitas digunakan untuk mengetahui suatu instrumen dapat dipercaya, handal dan akurat. Pengujian reliabilitas dalam penelitian ini menggunakan formula koefisien Alpha Cronbach.

\section{Uji Asumsi Klasik}

Uji asumsi klasik dimaksudkan agar uji regresi linier dapat dijadikan model yang bermanfaat untuk prediksi, karena penelitian ini menguji hipotesis dan menggunakan metode ordinary least squares (OLS) dalam analisisnya. Pengujian asumsi klasik yang digunakan dalam penelitian ini adalah uji normalitas, uji multikolinearitas dan uji heteroskedastisitas.

\section{Uji Kelayakan Model}

Ketepatan fungsi regresi sampel dalam menaksir nilai aktual dapat diukur dengan goodness of fit, yaitu melalui nilai koefisien determinasi, nilai statistik $\mathrm{F}$ dan $\mathrm{t}$. Perhitungan statistik disebut signifikan jika berada pada daerah kritis (H0 ditolak) dan sebaliknya tidak signifikan bila berada pada daerah H0 diterima

\section{Analisis Regresi Linier Berganda}

Analisis regresi linier berganda adalah hubungan secara linear antara dua atau lebih variabel independen $\left(\mathrm{X}_{1}, \mathrm{X}_{2}, \mathrm{X}_{3}\right)$ dengan variabel dependen $(\mathrm{Y})$. Analisis ini untuk mengetahui arah hubungan antara variabel independen dengan variabel dependen apakah masing-masing variabel independen berhubungan positif atau negatif dan untuk 
Tax payers satisfaction, Compliance tax payer memprediksi nilai dari variabel dependen apabila nilai variabel independen mengalami kenaikan atau penurunan. Data yang digunakan biasanya berskala interval atau rasio.

\section{HASIL PENELITIAN DAN PEMBAHASAN} Hasil Pengujian Validitas dan Reliabilitas Instrumen Penelitian

Hasil uji validitas variabel kepuasan wajib pajak ( $\left.\mathrm{X}_{1}\right)$, variabel penegakan sanksi pajak ( $\mathrm{X}_{2}$ ),variabel keadilan distributif (X3), dan variabel kepatuhan wajib pajak (Y) dapat diketahui bahwa semua item pertanyaan pada variabel tersebut mempunyai koefisien korelasi yang nilainya lebih besar dari 0,3 dan signifikan pada 0,05. Sehingga dapat dikatakan semua item pertanyaan valid atau lolos uji validitas. hasil uji reliabilitas seluruh variabel $\mathrm{X}_{1}, \mathrm{X}_{2}, \mathrm{X}_{3}$ dan $\mathrm{Y}$ menunjukkan bahwa nilai koefisien Cronbach s Alpha lebih besar dari 0,6 sehingga dapat disimpulkan bahwa semua butir pertanyaan terkait variabel penelitian ini reliabel atau lolos uji reliabilitas. Berikut disajikan tabel hasil uji validitas dan reliabilitas instrument penelitian :

\section{Tabel 1. Hasil Uji Validitas Instrumen Penelitian}

\begin{tabular}{|c|c|c|c|}
\hline \multirow{3}{*}{ Variabel } & \multirow{3}{*}{ Indikator } & \multicolumn{2}{|c|}{ Uji Validitas } \\
\hline & & Koefisien & Nilai \\
\hline & & Korelasi (r) & Signifikansi \\
\hline \multirow{4}{*}{ Kepuasan Wajib Pajak (X1) } & X3.1 & 0,813 & 0,000 \\
\hline & X3.2 & 0,719 & 0,000 \\
\hline & X3.3 & 0,687 & 0,000 \\
\hline & $\mathrm{X} 3.4$ & 0,814 & 0,000 \\
\hline \multirow{4}{*}{ Penegakan Sanksi (X2) } & $\mathrm{X} 2.1$ & 0,773 & 0,000 \\
\hline & $\mathrm{X} 2.2$ & 0,715 & 0,000 \\
\hline & $\mathrm{X} 2.3$ & 0,580 & 0,000 \\
\hline & $\mathrm{X} 2.4$ & 0,661 & 0,000 \\
\hline \multirow{5}{*}{ Keadilan Distributif (X3) } & $\mathrm{X} 1.1$ & 0,687 & 0,000 \\
\hline & $\mathrm{X} 1.2$ & 0,688 & 0,000 \\
\hline & $\mathrm{X} 1.3$ & 0,620 & 0,000 \\
\hline & $\mathrm{X} 1.4$ & 0,607 & 0,000 \\
\hline & $\mathrm{X} 1.5$ & 0,545 & 0,000 \\
\hline & Y1 & 0,733 & 0,000 \\
\hline
\end{tabular}




\begin{tabular}{|c|c|c|c|}
\hline & Y2 & 0,776 & 0,000 \\
\hline & Y3 & 0,649 & 0,000 \\
\hline & Y4 & 0,635 & 0,000 \\
\hline & Y5 & 0,737 & 0,000 \\
\hline & Y6 & 0,405 & 0,000 \\
\hline & Y7 & 0,669 & 0,000 \\
\hline & Y8 & 0,473 & 0,000 \\
\hline & Y9 & 0,709 & 0,000 \\
\hline & Y10 & 0,870 & 0,000 \\
\hline
\end{tabular}

Tax payers satisfaction, Compliance tax payer

Tabel 2. Hasil Uji Reliabilitas Instrumen Penelitian

\begin{tabular}{|l|l|}
\hline \multirow{2}{*}{ Variabel } & Uji Reliabilitas \\
\cline { 2 - 2 } & Cronbach's Alpha \\
\hline Kepuasan Wajib Pajak (X1) & 0,751 \\
\hline Penegakan Sanksi (X2) & 0,620 \\
\hline Keadilan Distributif (X3) & 0,619 \\
\hline Kepatuhan Wajib Pajak (Y) & 0,860 \\
\hline
\end{tabular}

Sumber : Data Olahan Peneliti

\section{Pengujian Asumsi Klasik}

\section{Hasil Uji Normalitas}

Hasil uji normalitas menunjukkan bahwa Asymp. Sig. (2-tailed) dalam One-Sample Kolmogorov-Smirnov Test adalah 0,397. Nilai ini lebih besar dari signifikansi 0,05, sehingga Ho diterima yang berarti data yang diuji terdistribusi normal.

Tabel 3. Hasil Uji Normalitas, One-Sample Kolmogorov-Smirnov Test

\begin{tabular}{|l|l|}
\hline & Unstandardized Residual \\
\hline Kolmogorov-Smirnov Z & 0,897 \\
\hline Asymp. Sig. (2-tailed) & 0,397 \\
\hline
\end{tabular}

Sumber : Data Olahan Peneliti

\section{$\underline{\text { Hasil Uji Multikolinearitas }}$}


Tax payers satisfaction, Compliance tax payer

018

Perhitungan SPSS versi 20 diketahui bahwa ketiga variabel independen memiliki nilai tolerance $>0,10$ yaitu untuk variabel kepuasan wajib pajak nilai tolerance 0,901 , untuk variabel penegakan sanksi nilai tolerance 0,165 dan untuk variabel keadilan distributif nilai tolerance 0,166 . Sedangkan untuk nilai variance inflation factor (VIF) < 10, masing masing yaitu variabel kepuasan wajib pajak nilai VIF 1,110, untuk variabel penegakan sanksi nilai VIF 6,046, dan untuk variabel keadilan distributif nilai VIF sebesar 6,042. Ini menandakan bahwa persamaan regresi ini memenuhi syarat uji multikolinearitas, berikut disajikan Tabel 4 Hasil uji multikolinearitas

Tabel 4. Hasil Uji Multikolinearitas

\begin{tabular}{|l|l|l|l|}
\hline No & \multicolumn{1}{|c|}{ Variabel } & Tolerance & VIF \\
\hline 1 & Kepuasan Wajib Pajak (X1) & 0,901 & 1,110 \\
\hline 2 & Penegakan Sanksi (X2) & 0,165 & 6,046 \\
\hline 3 & Keadilan Distributif (X3) & 0,166 & 6,042 \\
\hline
\end{tabular}

Sumber : Data Olahan Peneliti

\section{Hasil Uji Heterokedastisitas}

Dari perhitungan SPSS versi 20 menunjukkan bahwa tidak ada satupun variabel independen yang berpengaruh signifikan terhadap variabel terikat Absolut Residual. Dapat dilihat dari nilai signifikansinya sebesar 0,247 untuk variabel kepuasan wajib pajak, sebesar 0,967 untuk variabel penegakan sanksi pajak dan sebesar 0,573 untuk variabel keadilan distributif. Semua nilai tersebut lebih besar dari alpha $(\alpha=0,05)$, sehingga dapat ditarik kesimpulan bahwa model regresi ini memenuhi syarat uji heterokedastisitas.

Tabel 5. Hasil Uji Heterokedastisitas

\begin{tabular}{|l|l|l|l|}
\hline No & Variabel & t & Sig. \\
\hline
\end{tabular}




\begin{tabular}{|l|lll|}
1 & Kepuasan Wajib Pajak $\left(\mathrm{X}_{1}\right)$ & $-1,169$ & 0,247 \\
\hline 2 & Penegakan Sanksi $\left(\mathrm{X}_{2}\right)$ & 0,042 & 0,967 \\
\hline 3 & Keadilan Distributif $\left(\mathrm{X}_{3}\right)$ & 0,567 & 0,573 \\
\hline
\end{tabular}

\section{Analisis Statistik Deskriptif dan Persamaan Regresi}

Perhitungan SPSS versi 20 menunjukkan bahwa jumlah responden (N) adalah 70. nilai minimum variabel kepatuhan wajib pajak 29 dan nilai maksimumnya 46 dengan nilai rata-rata 37,01, nilai minimum variabel kepuasan wajib pajak 10 dan nilai maksimumnya 19 dengan nilai rata-rata 15,09, Variabel penegakan sanksi memiliki nilai minimum 11 dan nilai maksimum 19 dengan nilai rata-rata 14,97, sedangkan nilai minimum variabel keadilan distributif sebesar 14 dan nilai maksimumnya 23 dengan nilai rata-rata 18,56 .

Tabel 6. Statistik Deskriptif Data Uji

\begin{tabular}{|l|l|l|l|l|l|l|}
\hline \multicolumn{1}{|c|}{ Variabel } & N & Min & Max & Mean & Std.Deviation & Variance \\
\hline Kepatuhan WP & 70 & 29 & 46 & 37,01 & 5,026 & 25,261 \\
\hline Kepuasan WP & 70 & 10 & 19 & 15,09 & 2,351 & 5,529 \\
\hline Penegakan Sanksi & 70 & 11 & 19 & 14,97 & 2,085 & 4,347 \\
\hline Keadilan Distributif & 70 & 14 & 23 & 18,56 & 2,483 & 6,163 \\
\hline Valid N (listwise) & 70 & & & & & \\
\hline
\end{tabular}

Sumber : Data Olahan Peneliti

\section{Hasil Analisis Regresi Linear Berganda}

Hasil analisis regresi berganda dengan bantuan program SPSS versi 20 for windows menunjukkan ketiga variabel bebas kepuasan wajib pajak, penegakan sanksi pajak dan keadilan distributif, masing-masing berpengaruh pada kepatuhan wajib pajak khususnya wajib pajak Perusahaan Jasa Konstruksi. Hasil selengkapnya ditunjukkan pada tabel berikut ini. 
Tabel 7. Hasil Analisis Regresi Linear Berganda

Tax payers satisfaction, Compliance tax payer

\begin{tabular}{|l|l|l|l|l|l|}
\hline \multirow{3}{*}{ Variabel } & \multicolumn{2}{|l|}{ Unstandardized } & Standardized & & \\
\cline { 2 - 7 } & Coefficients & Coefficients & Sig. \\
\cline { 2 - 7 } & B & $\begin{array}{l}\text { Std. } \\
\text { Error }\end{array}$ & Beta & & \\
\hline (Constant) & 3,219 & 3,096 & & 1,040 & 0,302 \\
\hline Kepuasan WP (X1) & 0,383 & 0,159 & 0,179 & 2,405 & 0,019 \\
\hline Penegakan Sanksi (X2) & 0,943 & 0,419 & 0,391 & 2,251 & 0,028 \\
\hline Keadilan Distributif (X3) & 0,749 & 0,352 & 0,370 & 2,129 & 0,037 \\
\hline
\end{tabular}

Sumber : Data Olahan Peneliti

Berdasarkan Tabel 7 diatas dapat diringkas model persamaan regresi pengaruh kepuasan wajib pajak, penegakan sanksi pajak dan keadilan distributive pada kepatuhan wajib pajak sebagai berikut :

$$
\mathrm{Y}=3,219+0,383 \mathrm{X} 1+0,943 \mathrm{X} 2+0,749 \mathrm{X} 3+\mathrm{e}
$$

\section{Uji Kelayakan Model (Uji F) dan Koefisien Determinasi}

Kelayakan model regresi menganalisis untuk menguji pengaruh variabel independen yaitu variabel kepuasan wajib pajak, variabel penegakan sanksi pajak dan variabel keadilan distributif, pada variabel dependen yaitu variabel kepatuhan wajib pajak dilakukan dengan melakukan pengujian kelayakan model (Uji F). Hasil uji kelayakan model disajikan pada tabel 8 berikut ini :

Tabel 8. Hasil Uji Kelayakan Model (ANOVA ${ }^{\mathrm{a}}$ )

\begin{tabular}{|l|l|l|l|l|l|l|}
\hline \multicolumn{2}{|c|}{} & $\begin{array}{l}\text { Sum of } \\
\text { Sodel }\end{array}$ & Df & $\begin{array}{l}\text { Mean } \\
\text { Square }\end{array}$ & F & Sig \\
\hline \multirow{3}{*}{1} & Regression & 1196,466 & 5 & 239,293 & 28,022 & 000 \\
\cline { 2 - 7 } & Residual & 546,519 & 64 & 8,539 & & \\
\hline
\end{tabular}




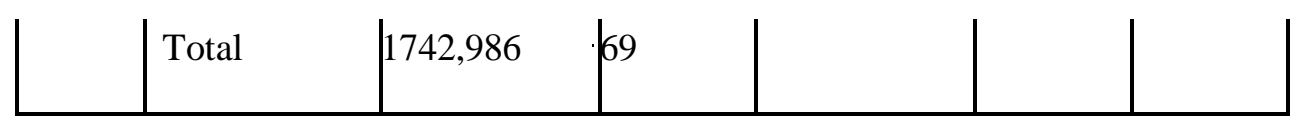

Sumber : Data Olahan Peneliti
Tax payers satisfaction, Compliance tax payer

Berdasarkan Tabel 8 dapat diketahui bahwa uji F menghasilkan nilai Fhitung sebesar 28,022 dengan signifikansi 0,000, nilai tersebut lebih kecil dari tingkat signifikansi yang ditetapkan $\alpha=0,05$ ( $\alpha=5$ persen). Koefisien determinasi menggambarkan sejauhmana variabel independen dalam model, mampu menjelaskan variabilitas variabel dependennya. Indikator koefisien determinasi yang digunakan dalam penelitian ini adalah Adjusted $\mathrm{R} \wedge 2$. Besarnya koefisien determinasi Adjusted $\mathrm{R} \wedge 2$ ditunjukkan pada Tabel 9 berikut ini.

Tabel 9. Koefisien Determinasi Model Summaryb

\begin{tabular}{|l|l|l|l|l|}
\hline Model & $\mathrm{R}$ & R Square & $\begin{array}{l}\text { Adjusted R } \\
\text { Square }\end{array}$ & $\begin{array}{l}\text { Std. Error of } \\
\text { the Estimate }\end{array}$ \\
\hline 1 & $.829 \mathrm{a}$ & .686 & .662 & 2,922 \\
\hline
\end{tabular}

Sumber : Data Olahan Peneliti

Berdasarkan Tabel 9 dapat diketahui koefisien determinasi Adjusted adalah sebesar 0,662. Ini berarti variabilitas variabel kepatuhan wajib pajak dapat dijelaskan oleh variabel kepuasan wajib pajak, penegakan sanksi pajak dan keadilan distributif sebesar 66,2\% sedangkan sisanya sebesar 33,8\% dijelaskan oleh variabel lain diluar model. Hasil uji F yang signifikan dan koefisien determinasi yang mendekati satu menunjukkan model regresi sudah baik sehingga dapat dilanjutkan dengan pembuktian hipotesis.

\section{Persamaan Regresi Berganda dan Hasil Uji Hipotesis}

Berdasarkan Tabel 7 sebelumnya diperoleh hasil uji regresi pengaruh parsial variabel independen kepuasan wajib pajak, penegakan sanksi pajak dan keadilan distributif, pada kepatuhan wajib pajak dengan rincian sebagai berikut :

1. Uji regresi variabel kepuasan wajib pajak pada kepatuhan wajib pajak diperoleh hasil koefisien $\beta=0,383$ dengan $p$-value sebesar $=0,019 / 2=0,0095$ (uji satu sisi) yang lebih kecil dari $\alpha=0,05$. Ini berarti bahwa kepuasan wajib pajak berpengaruh positif 
Tax payers satisfaction, Compliance tax payer

pada kepatuhan wajib pajak, sehingga hasil ini menerima hipotesis $\mathrm{H}_{1}$ yang menyatakan bahwa kepuasan wajib pajak berpengaruh positif pada kepatuhan wajib pajak. Ini berarti bahwa semakin tinggi kepuasan wajib pajak terhadap pelayanan yang telah diberikan Kantor Pelayanan Pajak maka akan mendorong wajib pajak badan khususnya perusahaan jasa kinstruksi untuk meningkatkan pemenuhan kewajiban perpajakanya.

2. Uji regresi variabel penegakan sanksi pajak pada kepatuhan wajib pajak diperoleh hasil koefisien $\beta=0,943$ dengan $p$-value sebesar $=0,028 / 2=0,014$ (uji satu sisi) yang lebih kecil dari $\alpha=0,05$. Ini berarti bahwa penegakan sanksi pajak berpengaruh positif pada kepatuhan wajib pajak, sehingga hasil ini menerima hipotesis $\mathrm{H} 2$ yang menyatakan bahwa penegakan sanksi berpengaruh positif pada kepatuhan wajib pajak. Berarti bahwa semakin tinggi penegakan sanksi yang dilakukan oleh Direktorat Jenderal Pajak terhadap wajib pajak akan cenderung mendorong untuk patuh dan taat terhadap kewajiban perpajakanya, sehingga wajib pajak akan memenuhi kewajiban perpajakanya dengan mempertimbangkan sanksi yang diberikan dalam memenuhi kewajiban perpajakanya.

3. Uji regresi variabel keadilan distributif pada kepatuhan wajib pajak diperoleh hasil koefisien $\beta=0,749$ dengan $p$-value sebesar $=0,037 / 2=0,0185$ (uji satu sisi) yang lebih kecil dari $\alpha=0,05$. Ini berarti bahwa keadilan distributif berpengaruh positif pada kepatuhan wajib pajak. Dengan demikian hasil uji hipotesis ini menerima hipotesis $\mathrm{H}$ з yang menyatakan bahwa keadilan distributif berpengaruh positif pada kepatuhan wajib pajak. Ini berarti bahwa semakin tinggi keadilan distributive yang diterima wajib pajak, akan cenderung mendorong wajib pajak badan khususnya perusahaan jasa kinstruksi untuk patuh dan taat dengan kewajiban membayar pajaknya.

\section{PENUTUP}

\section{Kesimpulan}

Berdasarkan hasil analisis dan pembahasan diatas dapat disimpulkan sebagai berikut :

1. Kepuasan wajib pajak dapat dibuktikan berpengaruh positif dan signifikan pada kepatuhan wajib pajak khususnya wajib pajak perusahaan jasa konstruksi hasil 
koefisien $\beta=0,383$ dengan $p$-value sebesar $=0,0095$ yang lebih kecil dari $\alpha=$ 0,05

2. Penegakan sanksi dapat dibuktikan berpengaruh positif dan signifikan pada Tax payers satisfaction, Compliance kepatuhan wajib pajak Badan khususnya Perusahaan Jasa Konstruksi hasil koefisien $\beta=0,943$ dengan $p$-value sebesar 0,014 yang lebih kecil dari $\alpha=0,05$.

3. Keadilan distributif berpengaruh positif dan signifikan pada kepatuhan wajib pajak Badan khususnya Perusahaan Jasa Konstruksi dengan hasil koefisien $\beta=$ 0,749 dengan $p$-value sebesar $=0,0185$ yang lebih kecil dari $\alpha=0,05$.

Keterbatasan-keterbatasan dalam penelitian ini adalah sebagai berikut :

1. Responden dalam penelitian ini adalah pimpinan perusahaan. Namaun dalam pengisian kuisioner penelitian ada beberapa yang menugasan kepada staf atau karyawannya dalam pengisian kuesioner sehingga akan menghasilkan data yang kurang baik. Penelitian selanjutnya dapat mempertegas dalam instrumen penelitian bahwa yang berhak mengisi kuesioner adalah pimpinan Perusahaan

2. Dalam penelitian hanya dapat menjelaskan variabel penelitian sebesar $66,2 \%$ sedangkan sisanya ditentukan oleh variabel lain sebesar 33,8\% yang tidak dimasukan dalam penelitian ini. Sehingga variabel penelitian yang digunakan kurang dapat menjelaskan pengaruhnya terhadap kepatuhan wajib pajak. Dan penelitian ini hanya menggunakan metode survey dengan kuesioner tanpa dilengkapi dengan wawancara atau pertanyaan lisan. Sebaiknya dalam mengumpulkan data dilengkapi dengan menggunakan pertanyaan lisan dan tertulis. 
Tax payers

satisfaction, Compliance tax payer

\section{DAFTAR PUSTAKA}

Albari. 2008. Pengaruh Keadilan terhadap Kepuasan dan Kepatuhan Wajib Pajak. Jurnal UNISIA. Vol. XXXI No. 69 September 2008.

Dharmawan, F. 2012. Pengaruh Keadilan Pajak Terhadap Tingkat Kepatuhan Wajib Pajak Pribadi, Studi Pada KPP Pratama Malang Selatan (tesis). Malang : Universitas Brawijaya. Dipublikasikan.

Dharmayanti, D. 2006. Analisis Dampak Service Performance dan Kepuasan Sebagai Moderating Variable Terhadap Loyalitas Nasabah. Jurnal Manajemen Pemasaran. Vol 1 No 1. Hal : 35-43.

Ghozali, I. 2011. Aplikasi Analisis Multivariate dengan Program IBM SPSS 19. Semarang : Badan Penerbit Universitas Diponegoro.

Gunadi. 2005. Akuntansi Pajak. Jakarta : PT. Gramedia Widiasarana.

Hernawan. 2006. Pemahaman Wajib Pajak Badan Atas UU PPh dan Penghematan Pajak. Jurnal Administrasi Bisnis, Vol 3, November 2006, Hal 846 - 868

Jatmiko, A.N. 2006. Pengaruh Sikap Wajib Pajak Pada Pelaksanaan Sanksi Denda, Pelayanan Fiskus Dan Kesadaran Perpajakan Terhadap Kepatuhan Wajib Pajak (tesis). Semarang : Universitas Diponegoro.

Jogiyanto. 2004. Metode Penelitian Bisnis : Salah Kaprah dan Pengalaman- Pengalaman. Cetakan Pertama. Yogyakarta

Koentarto, I. 2011. Analisis Faktor-Faktor Yang Mempengaruhi Kepatuhan masyarakat Dalam Melakukan Pembayaran Pajak Bumi Dan Bangunan. Sosioscientia, Jurnal Ilmu-ilmu Sosial.Vol 3.

Lubis, I. 2010. Menggali Potensi Pajak Perusahaan dan Bisnis dengan Pelaksanaan Hukum. Jakarta : Gramedia.

Mardiasmo. 2011. Perpajakan. Edisi Revisi. Yogyakarta: Andi. 
Maryati, E. 2014. Pengaruh Sanksi Pajak, Motivasi dan Tingkat Pendidikan Terhadap Kepatuhan Wajib Pajak (Studi Pada Wilayah Kantor Pelayanan Pajak Pratama Bintan) . Artikel. Tanjungpinang : Universitas Maritim Raja Ali Haji.

Tax payers satisfaction, Compliance tax payer

Mustikasari, E. 2007. Kajian Empiris Tentang Kepatuhan Wajib Pajak Badan di Perusahaan Industri Pengolahan di Surabaya. Simposium Nasional Akuntansi X. Makasar.

Novelia, K. R. 2009. Pengaruh Kualitas Pelayanan Terhadap Kepuasan Wajib Pajak (Suatu Studi untuk Pajak Kendaraan Bermotor di Satuan Administrasi Manunggal Dibawah Satu Atap Kota Depok). Jakarta : Universitas Indonesia.

OECD. 2001. General Administrative Principles - GAP004 Compliance Measurement.

Tax guidance series. Centre for Tax Policy and Administration.

Peraturan Menteri Keuangan Nomor 192/PMK.03/2007 Tentang Tata Cara Penetapan Wajib Pajak Dengan Kriteria Tertentu Dalam Rangka Pengembalian Pendahuluan Kelebihan Pembayaran Pajak

Republik Indonesia, Nota Keuangan dan Anggaran Pendapatan dan Belanja Negara Tahun Anggaran 2016

Robbins, S. P. dan Timothy, A. J. 2008. Perilaku Organisasi (Organizational Behavior). Buku 1. Jakarta : Salemba Empat.

Sanjaya, I. P. A. P. 2014. Pengaruh Kualitas Pelayanan, Kewajiban Moral dan Sanksi Perpajakan Pada Kepatuhan Wajib Pajak dalam Membayar Pajak Hotel. Jurnal Akuntansi Universitas Udayana 7.1.

Suartana, W. 2010. Akuntansi Keperilakuan, Teori dan Implementasi. Yogyakarta: ANDI.

Sugiyono. 2012. Metode Penelitian Bisnis. Cetakan Keenam Belas. Bandung : Alfabeta. 
Tax payers satisfaction, Compliance tax payer

lupui, I.G.K. 2005. Pengaruh Partisipasi Anggaran, Persepsi Keadilan Distributif, Keadilan Prosedural dan Goal Commitment terhadap Kinerja Dinas. Jurnal Bisnis dan Ekonomi. Vol. 9. No. 2.

Undang - undang Nomor 16 Tahun 2009 Tentang Ketentuan Umum dan Tata Cara Perpajakan ( KUP )

Undang - undang Nomor 18 Tahun 1999 Tentang Jasa Konstruksi Undang - undang Nomor 36 Tahun 2008 Tentang Pajak Penghasilan ( PPh )

Widodo, P. R. 2012. Pengaruh Persepsi Wajib Pajak Mengenai Petugas Pajak, Kepercayaan Wajib Pajak Dan Kepuasan Wajib Pajak Terhadap Kepatuhan Wajib Pajak (Studi Kasus Pada KPP Pratama Surabaya Simokerto) (skripsi). Jawa Timur : UPN Veteran. 